\title{
The effects of RU 41.740, a glycoprotein immunomodulating agent derived from Klebsiella pneumoniae, on intra-abdominal abscess formation in mice
}

\author{
J. J. FINLAY-JONES, A. N. BOYDEN, E. J. TILLETT, P. H. HART, L. K. SPEINCER, M. REZNIKOV \\ and P. J. MCDONALD
}

Department of Microbiology and Infectious Diseases, School of Medicine, Flinders University of South Australia, GPO Box 2100. Adelaide, South Australia 5001

\begin{abstract}
Summary. The prophylactic and therapeutic efficacies of the immunomodulating agent RU 41.740 (a glycoprotein extract from Klebsiella pneumoniae) were studied in a murine model of intra-abdominal abscess formation with Bacteroides fragilis, Escherichia coli, and bran as an abscess-potentiating agent. Parenteral injection of RU 41.740, either before or after injection of an abscess-inducing mixture (AIM), was associated with significantly diminished incidence and size of abscesses. Abscess incidence and size were significantly decreased by oral administration of RU 41.740 after, but not before, AIM injection. Abscess formation and resolution are the results of complex interactions of host defence mechanisms with bacteria and potentiating agent, and RU 41.740 has been shown previously to activate both macrophage and neutrophil function. These results indicate that activation of non-specific defences may protect against abscess development in chronic sepsis.
\end{abstract}

\section{Introduction}

Biological response modifiers (BRMs) are a group of heterogeneous substances that augment or diminish specific immune responses. Of particular interest has been their capability to augment host immune responses to malignant cells $\mathrm{s}^{1,2}$ and infectious agents. ${ }^{3}$ BRMs may also diminish immune responses in transplant rejection and autoimmune disease (e.g., cyclosporin A). ${ }^{4}$ Some BRMs are extracts or products of micro-organisms, and have modulating activities that augment non-specific host defences.

RU 41.740 comprises a mixture of molecules, predominantly glycoproteins from the cell wall of Klebsiella pneumoniae, and is an example of a BRM that augments responses of lymphocytes, ${ }^{\tilde{j}, 6}$ macrophages, ${ }^{7-10}$ and neutrophils. ${ }^{11-14}$ When used prophylactically, either parenterally or orally, it significantly protects animals against lethal parenteral challenges with Streptococcus pneumoniae, Listeria monocytogenes, Staphylococcus aureus, K. pneumoniae, and several viruses, ${ }^{15}$ as well as Candida sp. ${ }^{16}$ Its efficacy has not been tested in models of chronic bacterial infection.

We have examined the ability of RU 41.740 to inhibit intra-abdominal abscess development in an experimental model in mice, ${ }^{17}$ in which lesions and viable bacteria persist for months, ${ }^{17}$ and bacteria are sequestered within abscess neutrophils. ${ }^{18-20}$

\section{Materials and methods}

\section{Abscess induction}

Intra-abdominal abscesses were induced in 6-12week-old male BALB/c mice as described previously. ${ }^{17}$ Briefly, mice (usually in groups of 10 ) were given, by intraperitoneal (i.p.) injection, $0.05 \mathrm{ml}$ of an abscessinducing mixture (AIM) comprising $1 \mathrm{mg}$ of bran as potentiating agent, $(0.5-2.0) \times 10^{6} \mathrm{cfu}$ of Escherichia coli and $(0 \cdot 2-4 \cdot 0) \times 10^{9} \mathrm{cfu}$ of Bacteroides fragilis. The bacteria were taken from stocks frozen at $-80^{\circ} \mathrm{C}$. The AIM was prepared and loaded into syringes in an anaerobic chamber. Samples were taken for quantification of bacteria at the time of injection. Mice were killed by cervical dislocation 6 or 7 days after being given the AIM and examined for the presence of intra-abdominal abscesses. The location, number and weight of abscesses were determined, and representative abscesses were assayed for bacterial content as described previously. ${ }^{17}$

\section{Quantification of bacteria}

Dilutions of AIM in RPMI 1640 Medium (flow Laboratories, McLean, VA, USA) were plated in 
Table I. Effect on intra-abdominal abscess development of RU 41.740 given by i.p. injection 5, 3, and 1 days before i.p. injection of an AIM

\begin{tabular}{|c|c|c|c|c|c|c|c|c|}
\hline \multirow{3}{*}{$\begin{array}{c}\text { Experiment } \\
\text { no. }\end{array}$} & \multirow{2}{*}{\multicolumn{2}{|c|}{$\begin{array}{l}\text { Inoculum } \\
\text { (cfu/mouse) }\end{array}$}} & \multirow{3}{*}{$\begin{array}{c}\text { RU } 41.740 \\
\text { (mg/mouse/dose) }\end{array}$} & \multirow{3}{*}{$\begin{array}{l}\text { Number } \\
\text { of mice }\end{array}$} & \multirow{3}{*}{$\begin{array}{l}\text { Mortality } \\
\text { (at } 24 \mathrm{~h})\end{array}$} & \multicolumn{3}{|c|}{ Abscess } \\
\hline & & & & & & \multirow{2}{*}{ incidence } & \multicolumn{2}{|c|}{ weight (mg) } \\
\hline & E. coli & B. fragilis & & & & & median & range \\
\hline 1 & $5 \times 10^{5}$ & $2 \times 10^{8}$ & $\begin{array}{l}0 \\
0 \cdot 1\end{array}$ & $\begin{array}{r}10 \\
9\end{array}$ & $\begin{array}{l}0 \\
0\end{array}$ & $\begin{array}{l}5 \\
1\end{array}$ & $\begin{array}{c}10 \\
0 *\end{array}$ & $\begin{array}{l}0-111 \\
0-8\end{array}$ \\
\hline 2 & $1 \times 10^{6}$ & $4 \times 10^{8}$ & $\begin{array}{l}0 \\
0.1 \\
0.2\end{array}$ & $\begin{array}{r}10 \\
9 \\
8\end{array}$ & $\begin{array}{l}0 \\
0 \\
0\end{array}$ & $\begin{array}{l}6 \\
3 \\
0 \dagger\end{array}$ & $\begin{array}{c}49 \\
0 \\
0^{*}\end{array}$ & $\begin{array}{c}0-88 \\
0-66 \\
-\end{array}$ \\
\hline 3 & $2 \times 10^{6}$ & $4 \times 10^{9}$ & $\begin{array}{l}0 \\
0.3\end{array}$ & $\begin{array}{r}10 \\
9\end{array}$ & $\begin{array}{l}6 \\
0 \dagger\end{array}$ & $\begin{array}{l}4 \\
0\end{array}$ & $\begin{array}{l}35 \\
0^{*}\end{array}$ & $\begin{array}{c}25-76 \\
-\end{array}$ \\
\hline
\end{tabular}

* $\mathrm{p}<0.05$ versus control (Mann-Whitney test).

$\dagger \mathrm{p}<0.05$ versus control (Fisher's exact test).

quadruplicate on blood agar. Duplicate plates were incubated aerobically at $37^{\circ} \mathrm{C}$ for $24 \mathrm{~h}$ for the enumeration of $E$. coli. Similarly, duplicate plates were incubated anaerobically for $48 \mathrm{~h}$ for determination of the $B$. fragilis count by subtracting the aerobic $E$. coli count from the total anaerobic count of mixtures of the two species. Abscesses homogenised in a known volume of diluent in a glass grinder were similarly processed for the quantification of their bacterial content.

\section{Immunopotentiating agent}

RU 41.740 (Biostim ${ }^{\circledR}$; Roussel UCLAF, Paris) is an extract of $K$. pneumoniae strain K201 obtained by lysis, organic extraction, centrifugation and ultrafiltration. ${ }^{15}$ The mixture of molecules comprises c. $50 \%$ of "P1" glycoprotein $(95.5 \mathrm{kDa})$, c. $20 \%$ of " $\mathrm{F} 1$ " glycoprotein $(350 \mathrm{kDa})$, and c. $10 \%$ of "F2" glycoprotein $(65-100 \mathrm{kDa})$, with the remaining $20 \%$ containing lipids, nucleic acids, water and mineral salts. The batch number of the compound used was R 83-A-6831. A stock solution of RU 41.740 dissolved in mouse-osmolality phosphate-buffered saline (MPBS), ${ }^{21}$ was stored at $4^{\circ} \mathrm{C}$ until use. Doses of $0.01-0.30 \mathrm{mg}$ were used, usually in volumes of $0.4 \mathrm{ml}$ given by i.p. injection or $0.2 \mathrm{ml}$ given subcutaneously (s.c.), or doses of $0.25-4.0 \mathrm{mg}$ in $0.1 \mathrm{ml}$ were given orally. Control mice were given a similar volume of MPBS only.

\section{Timing of injection}

When RU 41.740 was used prophylactically, the indicated doses were given 5, 3 and 1 days before the AIM. When RU 41.740 was used therapeutically, it was given on days 2, 4 and 6 after the AIM.

\section{Statistical analysis}

For the comparison of mortality or abscess incidence in groups of mice, Fisher's exact test was used. ${ }^{22}$ For the comparison of abscess sizes or bacterial contents between groups, the non-parametric MannWhitney U-test was employed. ${ }^{22}$

\section{Results}

\section{$R U 41.740$ given i.p. before injection of AIM at the} same site

The results of three experiments in which RU 41.740 was administered by i.p. injection in three doses before injection of AIM are shown in table I. In the first experiment, three doses of $0.1 \mathrm{mg} /$ mouse protected the recipients against challenge with an AIM. In the second experiment, the bacterial challenge in AIM was doubled and $0.2 \mathrm{mg}$, but not $0.1 \mathrm{mg}$, of RU $41.740 /$ mouse/dose was protective. In the third experiment, the bacterial inoculum was increased further and there was significant mortality within $24 \mathrm{~h}$ of AIM injection in control mice. In mice given three doses of $0.3 \mathrm{mg}$ of RU 41.740 , there was significant protection against both the early mortality and subsequent abscess incidence. In a fourth experiment (data not shown), a single 0.2-mg dose of RU 41.740 given by i.p. injection 1 day before challenge with AIM gave significant protection against intra-abdominal abscess formation.

\section{$R U 71.740$ given i.p. after i.p. injection of an AIM}

Treatment with RU 41.740 in doses of $0.2 \mathrm{mg} /$ mouse, i.p., after injection of AIM, did not diminish abscess incidence (100\% in both groups). However, the median abscess burden in the treated group (33 $\mathrm{mg}$; range $2-267 \mathrm{mg}$ ) was significantly less than that in the control group (163 mg; range $55-519 \mathrm{mg}$; $\mathrm{p}<0.05$ in the Mann-Whitney test).

\section{$R U 41.740$ given s.c. before i.p. injection of an AIM}

The results of two experiments in which three doses of RU 41.740 were given by s.c. injection before i.p. injection of an AIM are given in table II. A dose of 
Table II. Effect on intra-abdominal abscess development of RU 41.740 given by s.c. injection 5, 3 and 1 days before i.p. injection of an AIM

\begin{tabular}{|c|c|c|c|c|c|c|c|}
\hline \multirow{3}{*}{$\begin{array}{c}\text { Experiment } \\
\text { no. }\end{array}$} & \multirow{2}{*}{\multicolumn{2}{|c|}{$\begin{array}{l}\text { Inoculum } \\
\text { (cfu/mouse) }\end{array}$}} & \multirow{3}{*}{$\begin{array}{c}\text { RU } 41.740 \\
\text { (mg/mouse/dose) }\end{array}$} & \multirow{3}{*}{$\begin{array}{l}\text { Number } \\
\text { of mice }\end{array}$} & \multicolumn{3}{|c|}{ Abscess } \\
\hline & & & & & \multirow{2}{*}{ incidence } & \multicolumn{2}{|c|}{ weight (mg) } \\
\hline & E. coli & B. fragilis & & & & median & range \\
\hline 1 & $4 \times 10^{4}$ & $8 \times 10^{8}$ & $\begin{array}{l}0 \\
0 \cdot 01 \\
0.05 \\
0 \cdot 1\end{array}$ & $\begin{array}{r}10 \\
10 \\
9 \\
10\end{array}$ & $\begin{array}{r}10 \\
7 \\
5 \\
7\end{array}$ & $\begin{array}{c}56 \\
32 \\
7^{*} \\
14\end{array}$ & $\begin{array}{c}21-87 \\
0-118 \\
0-42 \\
0-67\end{array}$ \\
\hline 2 & $1 \times 10^{6}$ & $6 \times 10^{8}$ & $\begin{array}{l}0 \\
0 \cdot 2\end{array}$ & $\begin{array}{l}10 \\
10\end{array}$ & $\begin{array}{c}10 \\
0+\end{array}$ & $\stackrel{45}{0 \dagger}$ & $\begin{array}{c}2-118 \\
\ldots\end{array}$ \\
\hline
\end{tabular}

${ }^{*} \mathrm{p}<0.002$ versus control (Mann-Whitney test).

$\div \mathrm{p}<0.005$ tersus control (Fisher's exact test).

Table III. Effect on intra-abdominal abscess formation of RU 41.740 given by s.c. injection 2, 4 and 6 days after i.p. injection of an AIM

\begin{tabular}{|c|c|c|c|c|c|c|c|}
\hline \multirow{3}{*}{$\begin{array}{c}\text { Experiment } \\
\text { no. }\end{array}$} & \multirow{2}{*}{\multicolumn{2}{|c|}{$\begin{array}{l}\text { Inoculum } \\
\text { (cfu/mouse) }\end{array}$}} & \multirow{3}{*}{$\begin{array}{c}\text { RU 41.740 } \\
\text { (mg/mouse/dose) }\end{array}$} & \multirow{3}{*}{$\begin{array}{l}\text { Number } \\
\text { of mice }\end{array}$} & \multicolumn{3}{|c|}{ Abscess } \\
\hline & & & & & \multirow{2}{*}{ incidence } & \multicolumn{2}{|c|}{ weight $(\mathrm{mg})$} \\
\hline & E. coli & B. fragilis & & & & median & range \\
\hline 1 & $1 \times 10^{6}$ & $7 \times 10^{8}$ & $\begin{array}{l}0 \\
0.05 \\
0.1\end{array}$ & $\begin{array}{r}10 \\
10 \\
9\end{array}$ & $\begin{array}{l}9 \\
6 \\
9\end{array}$ & $\begin{array}{l}55 \\
10^{*} \\
22\end{array}$ & $\begin{array}{l}0-99 \\
0-27 \\
6-212\end{array}$ \\
\hline 2 & $1 \times 10^{6}$ & $8 \times 10^{8}$ & $\begin{array}{l}0 \\
0 \cdot 2\end{array}$ & $\begin{array}{l}10 \\
10\end{array}$ & $\begin{array}{l}7 \\
2+\end{array}$ & $\begin{array}{c}26 \\
0 *\end{array}$ & $\begin{array}{l}0-95 \\
0-11\end{array}$ \\
\hline
\end{tabular}

* $\mathrm{p}<0.02$ versus control (Mann-Whitney test).

$\dagger \mathrm{p}<0.05$ versus control (Fisher's exact test).

Table IV. Effect on intra-abdominal abscess development of RU 41.740 given by mouth either $(A)$ before or $(B)$ after i.p. injection of an AIM

\begin{tabular}{|c|c|c|c|c|c|c|c|}
\hline \multirow{3}{*}{$\begin{array}{c}\text { Experiment } \\
\text { no. }\end{array}$} & \multirow{2}{*}{\multicolumn{2}{|c|}{$\begin{array}{l}\text { Inoculum } \\
\text { (cfu/mouse) }\end{array}$}} & \multirow{3}{*}{$\begin{array}{c}\text { RU 41. } 740 \\
\text { (mg/mouse/dose) }\end{array}$} & \multirow{3}{*}{$\begin{array}{l}\text { Number } \\
\text { of mice }\end{array}$} & \multicolumn{3}{|c|}{ Abscess } \\
\hline & & & & & \multirow{2}{*}{ incidence } & \multicolumn{2}{|c|}{ weight (mg) } \\
\hline & E. coli & B. fragilis & & & & median & range \\
\hline \multirow[t]{3}{*}{ (A) 1} & $1 \times 10^{6}$ & $6 \times 10^{8}$ & 0 & 10 & 6 & 26 & $0-54$ \\
\hline & & & $0 \cdot 25$ & 10 & 6 & 21 & $0-101$ \\
\hline & & & 1.0 & 9 & 7 & 36 & $0-71$ \\
\hline \multirow[t]{3}{*}{ (A) 2} & $1 \times 10^{6}$ & $5 \times 10^{8}$ & 0 & 9 & 9 & 54 & $41-102$ \\
\hline & & & $2 \cdot 0$ & 8 & 7 & 44 & $0-90$ \\
\hline & & & $4 \cdot 0$ & 9 & 9 & 61 & $16-101$ \\
\hline \multirow[t]{3}{*}{ (B) 3} & $1 \times 10^{6}$ & $4 \times 10^{8}$ & 0 & 10 & 10 & 73 & $44-149$ \\
\hline & & & $0 \cdot 25$ & 10 & 10 & 78 & $12-132$ \\
\hline & & & $1 \cdot 0$ & 10 & $6^{*}$ & $8 \dagger$ & $0-39$ \\
\hline
\end{tabular}

$0.2 \mathrm{mg} / \mathrm{mouse} /$ day gave complete protection; efficacy of lower doses varied. In a third experiment, an AIM comprising $2 \times 10^{6} \mathrm{cfu}$ of $E$. coli and $4 \times 10^{9} \mathrm{cfu}$ of $B$. fragilis was associated with significant mortality in controls $(60 \%)$ within $24 \mathrm{~h}$ of injection, but RU 41.740 given by s.c. injection protected against the early mortality $(0 \%)$ and subsequent abscess development (one of 10 in the treated group versus all four in the remaining controls; $p<0.05$, Fisher's exact test)

$R U 41.740$ given s.c. after i.p. injection of an AIM

The results of two experiments in which three doses of RU 41.740 were given by s.c. injection after i.p. injection of an AIM are given in table III. A dose of 
$0.2 \mathrm{mg} / \mathrm{mouse} /$ day resulted in significantly smaller abscess incidence and size. Smaller doses were of variable efficacy.

\section{RU41.740 given orally}

The experiments described above indicated that parenteral injection of RU 41.740, either at the site of sepsis (i.p.) or at a site distant from it (s.c.), before or after initiation of infection, significantly diminished abscess incidence or size or both. However, clinical use of the agent would be facilitated by oral administration. Other experimental studies indicated that oral RU 41.740 could protect against lethal parenteral challenge with various microbial pathogens. ${ }^{15,16}$ Therefore, oral administration at doses effective in these models, before and after i.p. injection of an AIM, was examined. An oral dose of $1 \mathrm{mg} /$ mouse on each of days 2, 4 and 6 after i.p. injection of the AIM inhibited abscess development; a similar dose given on days -5 , -3 and -1 did not; increased doses of RU 41.740 given before AIM challenge were also ineffective (table IV).

\section{Bacterial content of abscesses}

Representative abscesses from control and treated groups were examined by quantitative culture in most experiments. The bacterial content $(\mathrm{cfu} / \mathrm{mg})$ of abscesses that developed in RU 41.740-treated mice was not significantly different from that of abscesses of similar size in control mice.

\section{Discussion}

In these experiments, injection of an immunopotentiating agent, RU 41.740, diminished abscess incidence or size when given parenterally either at the site of challenge (i.p.), or remote from it (s.c.), before or after AIM challenge. When used prophylactically, RU 41.740 inhibited abscess development.

As RU 41.740 is extracted from K. pneumoniae, it might be argued that contaminating lipopolysaccharide could produce some of the effects seen. However, analysis of its constituents has shown that glycoproteins are the major components. ${ }^{15}$ Further- more, one of the effects of RU 41.740, stimulation of B lymphocytes, has been reproduced in a strain of mice that is unresponsive to polyclonal B-cell activation by lipopolysaccharide. ${ }^{5}$

When parenteral RU 41.470 was used therapeutically (i.e., after injection of AIM), inhibition of abscess development was less marked than with prophylactic administration. Abscess size and bacterial contents were significantly diminished. It is possible that the diminished abscess size may have resulted from the "diversion" of neutrophils from the encapsulated lesion (the abscess) to the site of RU 41.740 injection. However, abscesses in treated mice contained viable bacteria at concentrations similar to those in abscesses of equivalent size in control mice indicating that the host was not compromised. This is an important aspect of the effect of RU 41.470, as the size and bacterial content of abscesses is likely to correlate with the extent of clinical problems posed by abscesses.

When given by s.c. injection, RU 41.740 produced some dermonecrosis. It has been suggested that the oral route is effective for RU 41.740, and has a much higher LD50 than the parenteral route. ${ }^{23}$ With this, and the clinical usefulness of oral administration in mind, a series of experiments with oral RU 41.740 was done. RU 41.740 given by mouth after AIM challenge provided some significant protection against abscess development. Although this modest effect was in contrast to its efficacy when given parenterally, and its reported efficacy with septicaemic infection, ${ }^{15}$ it may stem from the complexity of the pathogenesis of chronic infection in the abscess model, such as persistence of abscesses in untreated animals for months. ${ }^{17}$ Bacterial persistence within abscesses is associated with diminished bactericidal activity of neutrophils from abscesses towards those bacteria engulfed in vivo. ${ }^{18-20} \mathrm{~T}$ lymphocytes, ${ }^{24}$ and the abscesspotentiating agent essential in this and other models, ${ }^{25}$ both contribute to abscess development in nonimmune hosts. However, it has been demonstrated that RU 41.740 affects both macrophages and neutrophils, ${ }^{7-14}$ comprising the likely mechanisms underlying its inhibitory effects on abscess development.

This work was supported in part by the National Health and Medical Research Council of Australia, Institut Roussel UCLAF (Paris) and Roussel Pharmaceuticals Pty Ltd, Australia, from whom we obtained the RU 41.740. We thank Drs J. Cameron and H. Wooller for their support and interest.

\section{References}

1. Oldham RK. Biological response modifiers. J Natl Cancer Inst 1983; 70: 789-796.

2. Reizenstein $P$, Mathe $G$. Immunomodulating agents. In: Fenichel RL, Chirigos MA (eds) Immune modulation agents and their mechanisms. New York, Marcel Dekker Inc. 1984: 347-361.

3. Drews J. The experimental and clinical use of immune-

modulating drugs in the prophylaxis and treatment of infections. Infection 1984; 12: 157-166.

4. Sigal NH, Dumont FJ. Cyclosporin A, FK-506, and rapamycin : pharmacologic probes of lymphocyte signal transduction Annu Rev Immunol 1992; 10: 519-560.

5. Wood CD, Moller G. Influence of RU 41.740, a glycoprotein extract from Klebsiella pneumoniae, on the murine immune system. 1. T-independent polyclonal B cell activation. $J$ Immunol 1984; 132: 616-621. 
6. Meroni PL, Barcellini W, Sgoutti C et al. Immunomodulating activity of RU 41740 : in vitro and in vivo studies on human lymphocytes. Int J Immunopharmacol 1987; 9: 185-190.

7. Radermecker M, Rommain M, Maldague MP, Bury T, Smets $P$. Increase in the number and the phagocytic function of guinea pig pulmonary and peritoneal macrophages following oral administration of RU 41740, a glycoprotein extract from Klebsiella pneumoniae. Int $J$ Immunopharmacol 1988; 10: 913-917.

8. Sozzani $S$, D'Alessandro $F$, Capsoni $F$ et al. In vitro modulation of human monocyte functions by RU 41740 (Biostim). Int $J$ Immunopharmacol 1988; 10: 93-102.

9. Vacheron F, Perin S, Kodari E, Smets P. Zalisz R, Guenounou M. Immunological activities of RU-41740, a glycoprotein extract from Klebsiella pneumoniae. III. Role of LPS-like and LPS-non-related molecules. Res Immunol 1989; 140 : $159-172$.

10. Meredith C, Scott MP, Pekelharing H, Miller K. The effect of Biostim (RU 41740) on the expression of cytokine mRNAs in murine peritoneal macrophages in vitro. Toxicol Let 1990; $53: 327-337$

11. Roch-Arveiller M, Abbouyi AE, Paul JL, Smets P, Raichvarg D, Giroud JP. Modulation by RU 41740 of oxidative metabolism and migration of polymorphonuclear leukocytes collected after induction of immune and non immune inflammations. J Biol Response Mod 1988; 7 : 199-203.

12. Capsoni F, Minonzio F, Venegoni $E$ et al. In vitro and ex vivo effect of RU 41740 on human polymorphonuclear leukocyte function. Int $J$ Immunopharmacol 1988; 10 121-133.

13. el-Abbouyi A, Paul JL, Roch-Arveiller M, Sarfati G, Giroud JP, Raichvarg D. Comparative effects of F1 and P1 fractions obtained from a Klebsiella pneumoniae glycoprotein extract (RU 41740) on polymorphonuclear leukocytes. J Biol Response Mod 1989; 8: 656-664.

14. Capsoni F, Minonzio F, Ongari AM, Bonara P, Guidi G, Zanussi $\mathrm{C}$. Increased expression of $\mathrm{C} 3 \mathrm{~b}$ and $\mathrm{C} 3 \mathrm{bi}$ receptors on human neutrophils and monocytes induced by a glycoprotein extract from Klebsiella pneumoniae (RU 41740). Int J Immunopharmacol 1991; 13: 227-233.

J. Med. Microbiol.-Vol. 38 (1993), 458-459

(c) 1993 The Pathological Society of Great Britain and Ireland

\section{BOOKS RECEIVED}

\section{Virological Aspects of the Safety of Biological Products. Developments in Biological Standardization, volume 75}

Edited by F. Horaud and F. Brown. ISBN 3-8055-5467-2 S. Karger, Basel. Pp. 264. $£ 82.60$.

This volume summarises the proceedings of a symposium held in London on 8-9th November 1990. The object of this meeting was to review the virological hazards associated with therapeutic products of biological origin and to consider the procedures designed to minimise the risks. The proceedings cover eight sessions relating to: (1) Regulatory aspects of the safety of biologicals; (2) Virus inactivation; (3) and (4) Bovine spongiform encephalopathy (BSE) and related agents; (5) Retroviruses; (6) and (7) Viral contamination and detection; and (8) Regulatory aspects of viral safety. The text concludes with a summary section. The discussions which followed the formal presentations are not included.

Inevitably with the proceedings of meetings, the individual contributions vary considerably in content and quality and some have become outdated in the 2 years since they were written. Nevertheless this volume contains useful infor-
15. Griscelli C, Grospierre B, Montreuil J et al. Immunomodulation by glycoprotein fractions isolated from Klebsiella pneumoniae. In: Yamamura $\mathrm{Y}$, Kotani S (eds) Immunomodulation by microbial products and related synthetic compounds. Amsterdam, Excerpta Medica. 1982: 261-265.

16. Smets P, Salles MF, Rommain M, Zalisz R, Yagello M, Guenounou M. RU-41740 (K. pneumoniae glycoprotein) enhances resistance to experimental candidiasis and stimulates phagocyte functions. Ann Inst Pasteur Immunol $1987 ; 138$ : $425-436$

17. Nulsen MF, Finlay-Jones JJ, Skinner JM, McDonald PJ. Intraabdominal abscess formation in mice: quantitative studies on bacteria and abscess-potentiating agents. $\mathrm{Br} \mathrm{J}$ Exp Pathol 1983; 64, 345-353.

18. Hart PH, Spencer LK, Nulsen MF, McDonald PJ, Finlay-Jones JJ. Neutrophil activity in abscess-bearing mice: comparative studies with neutrophils isolated from peripheral blood, elicited peritoneal exudates, and abscesses. Infect Immun 1986; 51 : 936-941.

19. Kenny PA, Spencer LK, McDonald PJ, Finlay-Jones JJ. Functional activity of individual abscess neutrophils from mice. Infect Immun 1990; 58: 4004-4010.

20. Finlay-Jones JJ, Hart PH, Spencer LK, Nulsen MF, Kenny PA, McDonald PJ. Bacterial killing in vitro by abscess-derived neutrophils. J Med Microbiol 1991; 34: 73-81.

21. Sheridan JW, Finlay-Jones JJ. Studies on a fractionated murine fibrosarcoma : a reproducible method for the cautious and a caution for the unwary. $J$ Cell Physiol 1977; 90: 535-552.

22. Siegel S. Nonparametric statistics for the behavioral sciences. New York, McGraw-Hill. 1956.

23. Edelstein R. RU 41.740, Biostim. Investigators brochure, 1st edn. Paris, Institut Roussel - UCLAF. 1982.

24. Nulsen MF, Finlay-Jones JJ, McDonald PJ. T-lymphocyte involvement in abscess formation in nonimmune mice. Infect Immun 1986; 52: 633-636.

25. Finlay-Jones JJ, Kenny PA, Nulsen MF, Spencer LK, Hill NL, McDonald PJ. The pathogenesis of intraabdominal abscess formation: abscess-potentiating agents and the inhibition of complement-dependent opsonisation of abscessinducing bacteria. J Infect Dis 1991; 164: 1173-1179.

mation which should be of interest to those involved in the manufacture or quality control of biologicals.

In section 1 , the need for a flexible approach in the regulation of biologicals is stressed by Petricciani who points to undue concern over residual contaminating DNA whereas viral contamination poses a real risk. However, even this has to be assessed on a case by case basis as contamination by avian retroviruses of substrates used to prepare influenza and yellow fever vaccines has led to no identified adverse effects. Other contributions emphasise the safe track record of continuous cell lines compared to primary cell cultures and summarise EEC legislation on biologicals.

In section 2, the historical problems encountered in the inactivation of polio and foot and mouth disease viruses for vaccine preparation are discussed, together with proposed procedures for the inactivation of viruses in blood products

Sections 3 and 4, on BSE and related diseases, contain some of the more interesting contributions to this volume, although inevitably in this topical field some statements, such as those relating to the geographical distribution of BSE, have become obsolete. The chapters by Prusiner on prion diseases and Kimberlin on BSE provide useful brief 